\title{
Binary Opposition as the Manifestation of the Spirit of Meiji in Natsume Sōseki's Kokoro
}

\author{
Richard Ahadi Christanda \& Ni Luh Putu Rosiandani \\ richardwolf99@gmail.com, puturosi@usd.ac.id \\ English Letters Department, Universitas Sanata Dharma
}

\begin{abstract}
Every period in history has its own unique identity. Meiji period in historical Japan is no exception to this, having its own identity called the spirit of Meiji. This research attempts to reveal this identity, which present in the story of Kokoro, by using binary opposition. Binary opposition allows comparing and examining contradicting elements. Since the spirit of Meiji is defined as having "two contradictory elements", therefore, binary opposition is suitable for revealing the spirit of Meiji.

The goal of this research is to show how binary opposition constitutes as a crucial element to the unique identity of Meiji period, which is the spirit of Meiji. In order to achieve this, two research problems are used as guides. One is how story of Kokoro presents the binary oppositions and two is how the spirit of Meiji manifests in the binary oppositions.

In this research, library research was conducted in order to collect the relevant data. It uses texts in both printed form and digital form. The primary source for the research is the novel Kokoro by NatsumeSōseki while the secondary sources are taken from various books and articles.

The first step in explaining the spirit of Meiji is to examine the binary oppositions within in the story. The binary oppositions itself are revealed through the characters and the setting of the story. Through these two elements, five binary oppositions are revealed. They are past against present, old against young, rural against urban, community against privacy, and family against individual. These binary oppositions are then compared to the situation in real-world Meiji period in order to validate whether they really are the spirit of Meiji or not. It is then, through this direct comparison, the binary oppositions are found mirroring the situation in the real Meiji period. Therefore, it can be concluded that binary opposition is the manifestation of the identity of Meiji period, which is the spirit of Meiji.
\end{abstract}

Keywords: binary opposition, Meiji period, spirit of Meiji.

\section{Introduction}

Kokoro is a novel written by Japanese writer NatsumeSōseki. Written in the end of Meiji period, the novel is one of the most famous examples of modern Japanese literature. The title "kokoro" is often translated into "the heart of things". The word itself, however, means "heart" or "mind".

Kokoro tells a story of a relationship between a student and a man whom he called Sensei, which means "teacher" or "mentor". The story highlights the problems that arose in the transition of Japanese society to the modern era. It talks about the changing role of family and individual in the modern era. Ultimately, it explores the development of modernity as thought process in the Japanese society at that time.

The story sets in the Meiji period, one of the most important eras in the Japanese history. Spanning from 1868 to 1912, the era brought a significant change to the Japanese society, transitioning the feudal Edo society to the modern Meiji one. The western powers brought modern technologies with them and 
consequently, their western values. Even though Japan prospered from the new western technologies, it was not without its sacrifice. Sōseki wrote in his diary, "We have had to do in ten years what the West took a hundred years to accomplish" (1966, pp. 280-281). The assimilation process was forced one. As a consequence, Japan was confused because they did not have enough time to digest all of that new information. This confusion was later called the spirit of Meiji. Furthermore, this confusion is akin to that of an identity crisis. Japanese people at that time were not sure whether to stay traditional or become modern. Thus, in a way, Kokoro can be read as a "witness testimony" to this confusion.

In Kokoro, almost everything can be divided into two groups. For example, the novel can be divided into two major parts. Each with different narrators acting as main characters. The setting of the story can also be divided into two. In one chapter it sets in Tokyo, an urban setting. In later chapter, it sets in the countryside, a rural setting. This arrangement of two different things is called a binary opposition. Furthermore, this arrangement is later proved to be crucial to the reason why the confusion in Meiji period happened.

This research discusses the significance of the binary oppositions portrayed in the novel. Firstly, the binary oppositions are identified. Then, those binary oppositions are analyzed with the concept of the spirit of Meiji in order to explain the connection with the story.

Based on the introductory passage above, the problems posed in this research are formulated as follows: (1) How does the story present the binary oppositions through the characters and the settings?; (2) How do the binary oppositions manifest as the spirit of Meiji?

There are two major parts to the analysis of this research. The first part is where the binary oppositions contained in the story is identified and the second part is where the connection between the binary oppositions and the spirit of Meiji is made.

\section{The Binaries}

\section{Past against Present}

In this binary opposition, the past and present refers to the internal chronological timeline of the story. Usually, when talking about the binary opposite of past, the answer would be future. However, the story rarely talks about the future. Therefore, the closest opposition that this research can talk about is the present.

The story is divided into three major chapters. The first two chapters are told from the student's perspective and the third chapter is told from Sensei's perspective. The first two chapters tell how the student become acquainted with Sensei and the student's relationship with his family after his graduation, respectively. Meanwhile, the third chapter tells about Sensei's past.

The first two chapters involves many dialogs. They are mostly written in direct quotations. This applies to conversations and the student's inner thoughts. The way the conversations are written are nothing of note.They are similar to most conversation with alternating speakers and occasional monologues.

The inner thoughts, however, are indeed something of note. Some of his inner thoughts are written directly with quotation marks, and if not, they are still in direct sentence instead of reported form. For example, on page 21, when the student is talking with Sensei about the Sensei's relationship with his wife, he thought:

\section{What struck me then as being odd was his last remark: "...we should be the happiest of couples." Why "should be"? Why did he not say, "We are the happiest of couples"? Was Sensei indeed happy? I could not but wonder (Sōseki, 1969).}

The directness of his remarks and the extensive use of direct quotations in conversations make the readers feel like they are the student and are experiencing his exact involvement in the story, effectively creating a feeling of real time engagement or being in the 
present.

The third chapter tells about Sensei's past life before the events in the first two chapters in the form of a very long letter from Sensei to the student. It contains the story of his uncle's betrayal, his love story with his wife-to-be, his betrayal towards his only good friend, his reasons for committing suicide, and his last will to the student.

Unlike the first two chapters, which have a lot of direct quotations, the third chapter features less of them. This chapter features more descriptions and reports compared to the first two chapters.

The usage of the quotations is also something of note in this chapter. Instead of the conversations written in a new paragraph each time a different character speaks, like the first two chapters do, the conversations are written inside the paragraphs. For example, on page 209, when Sensei cannot go to sleep, he called out to K:

"Hey!" "Yes?" he answered. So K had not gone to sleep either, I thought. "Haven't you gone to bed yet?" I said. He answered simply, "I will soon." Then I said, "What are you doing?" This time, there was no reply (Sōseki, 1969).

The way the conversation is written makes the readers rely much more on the narrator to tell them who is speaking compared to the much apparent physical paragraph break. This, combined with the fact that the chapter uses more descriptions, makes the chapter feel much more brief and rapid, which in turn disconnect the readers from the events described.This makes sense since Sensei is talking about the past.

\section{Old against Young}

In this binary opposition, old and young refer to the age of a person. Firstly, the old refers to the age group where the members are adults. There are many adults in the story, but only some are worthy of note. They are the old Sensei, the student's parents, and K's foster parents. These adults are characterized by having disagreements with the younger generation. This is because their world is different from the future world of the younger generation.

The old Sensei frequently finds his opinion not well-received by the student with the student often asking him what he means or simply disagrees. For example, when they are debating about the student's interest in Sensei, Sensei said, "You must try to be more sober in your opinions about me" (Sōseki, 1969, p. 29). However, the student disagrees saying, "But I am being sober" (Sōseki, 1969, p. 29). He, of course, being an intelligent and educated man, acknowledges this difference on opinion.

A similar case also happens with the student's parents. When the parents are suggesting having a party to celebrate the student's graduation, the student disagrees saying, "Don't do anything so elaborate for my sake, please" (Sōseki, 1969, p. 86). He simply does not like parties. Still, the parents insist on having it with the father saying, "We don't have to invite them, of course, but if we don't, there will be talk" (Sōseki, 1969, p. 86).

$\mathrm{K}$ once deceived his foster parents by using their money, which is supposed to be used for medical school, for his own educational interest. For a while, $\mathrm{K}$ hides this fact from his foster parents but eventually, he decided to tell them with a letter. The father is furious upon hearing it. Sensei describes the father's reply as, "He sent back a severe reply, in which he said that he could not possibly finance the education of one so unprincipled as to cheat his parents" (Sōseki, 1969, p. 169).

Secondly, the young here refers to characters below the age of adults. The members of this group are the student, young Sensei, and K. They are characterized by having displays of irrational behaviors. Being college students, they always try to act as objectively as they can. However, there are times where their passion trumps their common sense.

At the end of the second chapter, when the student quickly reads Sensei's last letter, he noticed a line saying, "By the time this letter reaches you, I shall probably leave this world-I shall in all likelihood be dead" 
(Sōseki, 1969, p. 122). Stunned by the fact that Sensei has committed suicide, he leaves his dying father to go Tokyo, hoping to see Sensei, saying, "Thus, in a desperate desire to act, I boarded the Tokyo-bound train" (Sōseki, 1969, p. 124).

The young Sensei, when shocked by the K's confession that he has a feeling towards Ojosan, quickly proposes an engagement to Ojosan's mother, not wanting to give his love interest to his own friend. He says that a voice whispered to his ear, "It is up to you to make the final move" (Sōseki, 1969, p. 220). He also says, "I must act before K does, I thought, and without his knowledge" (Sōseki, 1969, p. 220).

Furthermore, Sensei never had the courage to tell $\mathrm{K}$ about the engagement. When $\mathrm{K}$ knows about it, he commits suicide. He leaves a letter behind which, according to Sensei, says:

He had decided to die, he said, because there seemed no hope of his ever becoming the firm, resolute person that he had always wanted to be. [...] In this brief, businesslike letter, there was no mention of Ojosan. I soon realized that K had purposely avoided any reference to her. But what affected me most was his last sentence, which had perhaps been written as an afterthought: "Why did I wait so long to die?” (Sōseki, 1969, p. 230).

These irrational actions are what makes these young characters different from their adult counterparts.

\section{Rural against Urban and Community against Privacy}

The third binary opposition is the setting between rural against urban. They refer to the development level of an area. There are two binary oppositions in this particular point because they are strongly related.

Rural describes an area which is underdeveloped in terms of the area's advancement. People in rural areas live in modest houses. Moreover, people have strong community bonds in the rural areas since individualism, which is one of the western values, has not taken root yet.

In the story, two places fit these descriptions, they are the student's hometown and Sensei's hometown. The student states that his hometown is situated outside of Tokyo. He describes his house as a "large, old country house" (Sōseki, 1969, p. 85). Furthermore, when he describes the gate to his house, he said, "The old gate of our house had a thatched roof over it. The thatch had acquired a grey ashlike hue from years of exposure to wind and rain. One could see that in places, it had become very uneven" (Sōseki, 1969, p. 91).

For Sensei's hometown, the case is quite similar. He also comes from the countryside, as clearly stated on page 134 . He describes his house as having "a long history, and was not unknown in the district" (Sōseki, 1969, p. 134). Based on this fact, it is likely that Sensei comes from a well-off and famous family, which means his house is one of the largest, if not the largest, house in the area.

Besides the two houses, there is the community around the area of the houses itself. This part also talks about the community part from the next binary opposition. The community refers to a group people who has established an interpersonal relationship based on the same interest or the same geographical area. These people usually share the same moral values since they are so tightly knit together.

The tight-knit community is very apparent in the case of the student's hometown. When the student comes home after his graduation, his parents immediately proposes a dinner party to celebrate it. $\mathrm{He}$ "immediately objected" (Sōseki, 1969, p. 86). However, his parents insist on having it saying that, "if we don't, there will be talk" (Sōseki, 1969, p. 86). In the countryside, and especially at that time, graduation from a higher education is a major occasion. Therefore, the family in question is expected to throw some kind of party as a way to tell everyone in the neighborhood. If they fail to do that, then there will be gossips about them, since, as the father puts it, "Country people are rather fussy and resentful" (Sōseki, 1969, p. 86). 
Sometime after the cancellation of the party, the student receives a job offering from his friend. The opening is not a significant one and the student declines the offer. When he tells his parents about it, they say, "Surely, there is no need for you to go to such a place. You will get a better offer" (Sōseki, 1969, p. 93). This is because they are, in the words of the student, "expecting their universityeducated son to find an important position with a huge salary" (Sōseki, 1969, p. 93). Just like the previous case, the parents are concerned about their reputation in the community. In a rural area, the prestige of a family is determined from the occupation of the children.

In the case of the community in Sensei's hometown, he mentions one thing that is related which is when he considers selling the house he said, "In the country, as you are probably well aware, it is a very serious thing to tear down or sell a house with a long tradition when there is an heir" (Sōseki, 1969, p. 134). This is most likely because of his family's reputation in the area. A famous family like Sensei's family usually has a significant influence in the area. They often have an integral role in the social gatherings like festivals and traditional religious ceremonies.

From the points above, it is clear that the student's hometown and young Sensei's hometown represent the rural part of the binary opposition and their respective community represent the community part.

The second element of the binary is urban. It describes a developing area in terms of the area's advancement. Large buildings are common and high population is expected. Western technologies are used extensively by the population. Moreover, western moral values have penetrated the urban society.

In the story, only one place fits the description above, which is Tokyo. The first mention of Tokyo as a setting is when the student returns from his vacation in Kamakura in the first chapter page 7, "I returned to Tokyo at the end of the month" (Sōseki, 1969, p. 7). Trams are mentioned a few times in the story. Since trams are western technology and universities are a form of western education, this shows that western influences are strong in Tokyo. Another factor that solidifies the image of Tokyo is the districts. They are, for example, Ueno, which is a park where Sensei and the student once take a walk at, Zoshigaya, where $\mathrm{K}$ is buried in a cemetery there, and Koishikawa, where Ojosan's house is.

The urban, however, is not only defined by the elements above. It is also defined by privacy, which is a part of the binary opposition between community and privacy. In the story, there are no mentions of neighbors while story is set in Tokyo. The student, who lived in a boarding house, should have neighbors next to his room but the story does not mention any of them. The same goes for Sensei's house. Sensei lives in a neighborhood but not once the story mentions any neighbors. There are mentions of crowds but they are only described so simple like, "There was a large crowd around us, and every face in it looked happy" (Sōseki, 1969, p. 26). After that, the student makes no further comment on the crowd. Occasions like these are common in the story when the characters mention other people but only describe them in such a simple way.

The lack of mentioning other people or the lack description itself shows that the student or Sensei do not particularly care about other people especially strangers. This means they value their privacy much more than socializing. Furthermore, privacy is much more valued in western culture than in Japanese culture.

From the points above, it is clear that Tokyo represents the urban part of the binary opposition and the lack of mentions of neighbors and friends represent the privacy part.

\section{Family against Individual}

Family and individual refer to the responsibilities toward the family and responsibilities as an individual, respectively. The first element of the binary is the family. It refers to the amount of responsibility one has toward the family. In the story, this is reflected in the responsibility to support the family and the responsibility to continue the legacy of the 
family.

The responsibility to support the family is one of the student's responsibility as a descendant of his family. The student's parents want the student to have a job befitting his university education (Sōseki, 1969, p. 93), which is usually highly paid, and thus able to support his family Therefore, the parents are putting their lives in their children's hands, effectively placing a big responsibility into their children's shoulders.

This feeling of burden is exactly what the student feels. The feeling of burden is then reflected in his actions. When his mother tells him to write a letter asking Sensei for a job opening, he did it reluctantly. The student just says, "Yes", half-heartedly and leave the room (Sōseki, 1969, p. 95).

Another responsibility is the responsibility to continue the legacy of the family. As mentioned in the previous binary opposition, Sensei has 'a house with a long tradition', which he describes as having "a long history and was not unknown in the district" (Sōseki, 1969, p. 134). From that remark, Sensei is also saying that his house is famous in the area. If the house itself is famous, so is the occupants.

The fame of Sensei's family is the reason why Sensei has the responsibility to continue his parents' legacy and uphold the family's reputation in the area. He is supposed to stay there and continue doing whatever his family has done for the community over the years. He himself says that if he ever decided to sell his house or tear it down it would be viewed as controversial (Sōseki, 1969, p. 134) since the people of the area could view it as abandoning his responsibility.

K's foster father wants $\mathrm{K}$ to pursue the same path as he is, which is to be a medical doctor. This is K's responsibility as the son of a doctor. K's foster family is a wealthy and thus famous family. To summarize, the family in the binary opposition family against individual refers to the responsibility of the descendant of the family toward the family themselves.

The second element of this binary opposition is individual. If previously family refers to responsibility one has to the family, individual refers to the freedom one has as an individual.

At the very end of chapter two, the student's father's condition grows increasingly worse with his death seemingly imminent. One might think that one should stay with a dying person until their death. At one point, when skimming through his letter the student reads a line that says Sensei has committed suicide (Sōseki, 1969, p. 122). The student decides hurriedly to go to Tokyo saying, "Thus, in a desperate desire to act, I boarded the Tokyobound train" (Sōseki, 1969, p. 124). The student has forsaken his dying father to see Sensei, who, in all likelihood, has died. The student prioritizes his own desire to see Sensei over the common sense of staying with his dying father. He betrays his family's expectations in order to see a man who is, in alllikelihood, already dead.

The previous element of this binary opposition explores Sensei's family and his responsibility to continue the legacy of his family. However, Sensei abandons his responsibility. Because of his uncle's betrayal, he becomes distrustful of other people and then leaves his hometown forever saying, "I had decided to leave, and stay away from home for a long time to come. I had made a vow never to see my uncle's face again" (Sōseki, 1969, p. 143). Sensei prefers to leave because of his hatred toward his uncle rather than to stay, swallow his anger, and uphold his responsibility to the community.

In the previous element, K's family is examined to reveal K's responsibility toward his two families, original and foster family. The former is to be a good child and the latter is to become a doctor, continuing on his foster father's footsteps. However, K goes against his father's wishes and pursues his own educational interest. Sensei says something about this, saying, "K's foster parents had originally sent him to Tokyo with the intention of making him a doctor. But $\mathrm{K}$, who was very stubborn, had come to Tokyo resolved never to become a doctor. I reproached him, pointing out that he was deceiving his foster parents" (Sōseki, 1969, p. 166). K, however, never fears 
the consequences of his actions and still decides to use the money for his own interest. $\mathrm{K}$ chooses to pursue his own educational interest over his father's wishes.

In summary, the individual in the binary opposition family against individual refers to act of individualism exhibited by the characters namely the student, Sensei, and K.

To conclude this part of analysis, a look at the bigger picture of all binary oppositions is needed. There are five binary oppositions, namely past against present; old against young; rural against urban; community against privacy; and family against individual. Notice that a pattern emerges. The former element represents the traditional values and the latter represents the modern one.

The traditional elements of the binary oppositions are the past, the old, the rural, the community, and the family. Sensei's recount of his past in the form of letter represents the past. The adults who often have disagreements with the young represents the old. The student's and Sensei's hometown, or the countryside, represents the rural. The tightknit group of people in the rural area represents the community. Finally, the familial responsibility that the descendants of a family has represents the family. These are all old things.

On the other hand, the modern elements of the binary oppositions are the present, the young, the urban, the privacy, and the individual. The student's telling his story of the present time, the curious and passionate young students, the sprawling urban jungle of Tokyo, its privacy-conscious setting, and the display of individualism are all new things. They represent a new and modern era for Japan brought by the Meiji Restoration and subsequent western cultural revolution.

\section{The Binaries and the Spirit of Meiji}

This part of the analysis discusses the connection between the binary oppositions and the Spirit of Meiji. The first order of business is to establish a context. Firstly, a definition and clarification of the spirit of Meiji is required. At first glance, since this whole research involves binary opposition, one might think that if the spirit of Meiji exists, then, the antithesis, 'the Spirit of Not-Meiji' also exists.
The reasoning behind this is simple. Since Meiji period is the modern era, the supposedly NotMeiji era is the traditional era, each with their own unique 'Spirits'. This is, however, not the case. Isamu Fukuchi argued that the spirit of Meiji "embodied two contradictory aspects", which, according to Fukuchi, are "caused by the confusion and the conflict involved in modern ideals and traditional morality" (1993, p. 488). Confusion and conflict are the keywords here. This means that the spirit of Meiji is caused by mixing up the old traditional morality and the new modern ideals which subsequently produce a clash of incompatibility between these values. Therefore, it can be said that the Meiji period is the era where Japanese people are confused whether to stick to the old traditional morality or to embrace the new modern ideals. This, consequently, resulted in the aforementioned conflict.

Secondly, a background to the spirit of Meiji is needed. Meiji period was kickstarted by the Meiji Restoration, a national and cultural revolution that aims to modernize Japan to keep up with the more powerful western countries. This revolution was done by restoring the imperial rule and introducing new and modern western values. However, this introduction was too sudden and there was too much to absorb at once that it made Japan confounded. This resulted in the confusion and the subsequent conflict in the spirit of Meiji.

Japanese people were worried of the implications if they embrace the new modern ideals but, at the same time, they did not want to be left behind by sticking to the old traditional morality either. This effectively splits the national consciousness into two, the pro-traditional conservationist and the promodern progressivist. The conservationists were represented by the Seikyōsha, led by Miyake Setsurei, Kuga Katsunan, and Shiga Shigetaka and the progressivists were represented by the Min'yusha, led by Tokutomi Sohō.

\section{Reconciling the Past and the Present}

The fundamental reason why the spirit of Meiji existed is the difficulty of reconciling 
Japan's past and her present. Japanese people were confused whether to stick to the old traditional moralityor to embrace the new modern ideals. They were not sure whether they can trust the future of their country to these modern ideals or not.

The progressivist Min'yusha argued that they should just copy everything that western countries taught them. The western powers were far more technologically advanced than the Japanese, much more prosperous because of it, and subsequently have much more power. However, the conservationist Seikyosha argued that, by blindly copying anything western, they would gradually lose their identity as a Japanese. Instead, they were advocating selective borrowing while taking things from their past as a unique identity and also as a guiding post.

Japanese people, especially those who were literate and educated, were genuinely torn over choosing which way. Whether to throw away their past completely and run blindly into the future or to take their past with them and advance carefully, they could not decide. Pyle's conclusion about the whole predicament is as follow:

Disoriented by the accelerated process of history, she required some meaningful way of relating her past to the present and future, some clear perspective and sense of direction that would function as a binding and integrative force, enabling her people to act in concert and deal effectively with her domestic and international problems (Pyle, 1969, p. 203).

As discussed before, the first and second chapters in Kokoro represents the present element of the binary opposition between past against present, while the third chapter represents the past element. However, there is something unusual about the arrangement of the chapters. The present is told first, while the past is told later, and the reason of this peculiarity lies in Sensei himself.

After sometime, the student is curious about Sensei's past since he wants to know what makes Sensei who he is today. However, Sensei only promises the student to tell his past in the indefinite future. Sensei is hesitating because he has a very traumatic past. His parents die before he is twenty, he is betrayed by his uncle, he betrays his own friend, $\mathrm{K}$, and $\mathrm{K}$ commits suicide because of it. It is normal wanting to forget such tragedyridden past and thus not telling anyone about it. However, at the same time, Sensei does not want to go back at his own promise. He writes about this in his letter, saying:

Often, I was tempted to abandon the task,
and so break my promise to you. But every
time I dropped my pen thinking I could not
go on, I found that before a full hour had
passed, I was writing once more. You may
take this as a manifestation of my naturally
strong sense of obligation (Sōseki, 1969, p.
127).

He then continues:

But that is not the only reason why I wanted to write this. You see, apart from any sense of obligation, there is the simple reason that I want to write about my past. Since my past was experienced only by me, I might be excused if I regarded it as my property, and mine alone. And is it not natural that I should want to give this thing, which is mine, to someone before I die? At least, that is how I feel. On the other hand, I would rather see it destroyed, with my life, than offer it to someone who does not want it (Sōseki, 1969, p. 128).

Sensei's predicament, whether he should write or not write, is similar to the predicament that the Meiji Japanese had. They both were not sure whether to forget their past completely and move on or to bring with them and pass it to the future generation. In the end, Sensei decides to tell the student about his past because he feels his past is important to the student. This is why the chapters are arranged the way it is. The past is told after the present because it is important, both for the student and the reader. If the past is not important, it would be told before the present, just like any other past. 


\section{Obsolescence of the Old and the Authority of the Young}

As said before, Meiji period brought many things to Japan. One of them is western education. This brought new field of studies such as English language and literature, physics, biology, psychology, and western philosophy. These new field of studies were proven to be beneficial to the western countries, so therefore many young Japanese at the time enrolled in such studies in the hopes of becoming useful to the country. However, the new education not only brought knowledge with them, but also power. As Pyle explained:

Since graduates of the Western schools were often the best prepared for the new professions, young Japanese, and not their elders, were often "the effective guides to a new world, and they thereby gained a strange, anomalous authority," an authority sometimes difficult to reconcile with the traditional structure of social life (1969, p. 12).

This newfound authority compounded the fact that traditional social classes were abolished as a result of the Meiji Restoration. Because of these two reasons, the young generation had the power and the means to oppose their elder. And oppose they did, because their incentive was, as Tokutomi argued:

Young and old were also frequently in conflict in Western society, he [Tokutomi] observed, but their differences were not so great as in Japan, where the pace of change had been more rapid. The "old people of the feudal age" could not understand the problems of youth in the new Japan: "A youngster of sixteen confronts problems of life (seikatsuteki no mondai) that his ancestors, even his elders today, never imagined." (Pyle, 1969, p. 33)

In short, western education gave young Meiji Japanese a new power and authority like never before and they used it to oppose the old.

In Kokoro, the authority of the young is manifested in the actions of the student, young
Sensei, K. In the previous part of the analysis, these three characters are revealed to represent the young element in the binary opposition old against young by enrolling in university and exhibiting passionate actions. These passionate actions plus other actions that have been discussed are a form of opposition against the old. The student rejecting his parents' proposal for a graduation dinner, Sensei opposing his uncle, and $\mathrm{K}$ tricking his foster parents, these are all actions revolting against the authority of the elders. Furthermore, more often than not, the elders are not in agreement with these actions. The student's parents insisted on having the dinner. Sensei's relatives tried to stop the feud between Sensei and his uncle. K's father was angry upon hearing his deception. These confrontations are caused from the newfound power that the young had discovered upon receiving western education just like the real young Meiji Japanese.

\section{Rural Hinterland and Urban Haven}

Another thing that Meiji Restoration brought to Japan was western technology. It introduced many new technologies such as industrialization, electricity, telegrams, and steam engine. Many cities, such as Tokyo, were modernized by these new technologies. However, not all people can enjoy the convenience that these new technologies brought with them. This is because they were mainly available in big cities only. Therefore, people on the countryside only get some of the benefits of these technologies.

Add to the fact that factories were only available in the city left the villagers with no other option than continue working on their rice fields. Furthermore, because of the promise that western education offered, many young people left their hometowns and enrolled in western schools and universities, which were only available in the city. This means the elderly were left behind to tend the fields. The whole situation created a complicated circumstance where the elderly, who were mainly conservationists, were divided by the technological, educational, and geographical gap with the young generation, who were mainly progressivists. As Pyle, summarizing Thomas Smith's findings, said: 
Despite the growth of industry, which fostered attitudes destructive to tradition in urban areas, extraordinary continuities in the mode of Japanese farming helped to perpetuate old values in the countryside. [...] Since the number of persons employed in agriculture remained stable, accounting for over 50 percent of the population as late as 1930, "the countryside remained a vast and populous hinterland of conservatism" (1969, pp. 122-123).

In other words, the various gaps between rural and urban in Meiji Japan had made rural into a hinterland for conservationist and urban into a haven for progressivists.

In Kokoro, the gap between rural and urban are manifested in the student's and Sensei's hometown and Tokyo, respectively, as revealed in the previous part of the analysis. The two hometowns still have strong communities as shown with the student's father concern with his reputation and also Sensei's concern if he ever wants to sell or tear down his house. On the other hand, Tokyo, with its privacy-minded inhabitants, is completely different as shown with the lack of mentions or descriptions about other people, demonstrating how prevalent western values are. Just like the countryside in real Meiji Japan, the two hometowns are hinterlands of conservationism and just like the cities in real Meiji Japan, Tokyo is a haven of progressivism.

\section{Family Obligation and Individual Success}

As discussed before, another effect of Meiji Restoration is the introduction of western values, especially individualism. The effect of this new moral value that emphasizes personal desire rather than the group's greater good was felt very strongly by Meiji Japanese because of its contrast to the traditional groupcomes-first principle that the Japanese had for a long time. Furthermore, since many of the young Meiji Japanese took western schools, because of the education reform, they subconsciously inherited this value from their western teachers.

As the one on the progressive side, the Min'yusha used individualism as an argument for their cause and attacked the old principle of the group. They argued, in Kokumin no Tomo, that "democratic ethics encouraged the individual to rely on his own efforts, knowledge, and skills, rather than on the joint effort of his group" (Pyle, 1969, p. 131). Furthermore, they continued the attack, this time on the family system, saying:

\section{The weight of family obligation bore heavily on ambitious young men, preventing them from achieving individuality and from succeeding in the world. [...] Rather than face ostracism, young men sacrificed their spirit and ambition on the altar of family obligation. And this burden continued inexorably from generation to generation: "It is the fault of the family system that youth must sacrifice themselves for today's elders, who once sacrificed themselves for their own elders.. - Today's elderly take out the bitterness of their past on our young people. Thus, if we do not change. . . to a system of individualism, we shall never be able to overcome the evils of family tyranny" (Pyle, 1969, p. 135).}

In other words, the Min'yusha argued that the old moral value of group priority and family system were detrimental to the progress of Japan into becoming a modern country and pushed for a democratic and individualistic way of thinking and acting.

However, Min'yusha's argument did not stop the conservationist from having their own opinion. They still prefer to stick to their old moral values. As shown in the previous point, a vast amount of land in the country was still "hinterlands of conservatism" after all.

In Kokoro, the feud between familial values and individual values are manifested in the binary opposition family against individual. The student's parents insisting on he having a prestigious job to support the family, Sensei's and K's parents desires to continue the legacy of their respective families, they are all defending the old values, just like the conservationist. On the other hand, the student leaving his father and $\mathrm{K}$ deceiving his foster parents are demonstration of individualism, just like the progressivists' 
argument. Furthermore, even though Sensei leaving his hometown is out of hatred against his uncle, the people he left behind might feel he is being selfish, and thus individualistic. Just like the real Meiji Japanese, there are those who defend the group and there are also those who choose to be themselves in the story.

\section{Remain Traditional or Become Modern}

To conclude this part of analysis, the reason behind the confusion in 'the Spirit of Meiji' will be discussed here. After the Meiji Restoration, Japan had two choices, remain traditional or become modern. One might think that the most rational choice was to become modern since choosing the former means going backwards. However, it was not as simple as it sounds. By going forward to modernity, they risk losing their identity. An identity that had been forged over time and effort. Furthermore, an identity is an important part of something, whether it be a person or a nation. In Pyle's words this identity is called "national consciousness", as in:

They [young Japanese] grew up in a period marked not only by extensive cultural borrowing from the West, but also by rapidly mounting national consciousness; and the coincidence of these conditions created a dilemma to which young intellectuals were particularly sensitive (1969, p. 79).

The dilemma is that by going forward, they risk losing their identity, but by going backwards, they risk being left behind. Unable to choose, the Meiji Japanese were stuck in the middle, not quite modern but not traditional either.

In Kokoro, the dilemma is manifested in the form of Sensei. Sensei is a man with a strong sense of responsibility, a trait strongly associated with traditional values. He invited $\mathrm{K}$ to live with him because he wants $\mathrm{K}$ to be happier. He properly asks his wife's mother for permission to marry her when he decides to. He takes care of his mother-in-law until her death. Finally, he fulfilled his promise to the student to tell him about his past. It might be weird to say that Sensei is a responsible person since it has been revealed that Sensei leaves his hometown and his familial responsibility. However, he leaves because he hates his uncle, not because of some inherently irresponsible reason. If Sensei never fought with his uncle, he would have stayed since he actually loves his family.

However, as much as responsible he is, there are things that make him look irresponsible. He makes $\mathrm{K}$ commits suicide, which is the exact opposite with his original intention, to make him happier. He never tells his wife his feelings about his past, saying that he does not want to "defile" her with his traumatic memories. Finally, the most important thing is that he commits suicide, effectively abandoning all of his responsibilities, his wife, and the student.

There are other things that he does too. $\mathrm{He}$ is a university graduate but he does not have a job. He is an educated man but he occasionally pees on the ground. He says he does not hide anything from the student about his past but he does. He says he wants his wife to be happy but he always talks about things that does not make her happy (e.g. about his death). These are all contradictory things about Sensei. It is as if he does not know what is right or what is wrong.

Sensei is 'the Spirit of Meiji' itself. He wants to move on from K's death but he felt he is responsible for his death and therefore he needs to atone for it. He wants to go forward but he does not want to throw his past away. Because if he does, he will stop being himself. In the end, all he can do is being in the middle, saying, "Finally, I decided to go on living as if I were dead" (Sōseki, 1969, p. 243). His description is akin to that of a zombie, a being not fully alive but not dead either.

Furthermore, in the end of his letter, Sensei said that his reason of committing suicide is 'the Spirit of Meiji' itself saying:

I felt as though the spirit of the Meiji era had begun with the Emperor, and had ended with him. I was overcome with the feeling that I and the others, who had been brought up in that era, were now left behind to live as anachronisms. I told my wife so. She laughed and refused to take me seriously. Then she said a curious thing, albeit in jest: "Well then, junshi is the 
solution to your problem." (Sōseki, 1969, p. 245).

Junshi means "following one's lord to the grave" according to McClellan, the translator of the novel. Then Sensei replied to his wife, "I will commit junshi if you like; but in my case, it will be through loyalty to the spirit of the Meiji era" (Sōseki, 1969, p. 245). This reason is indeed quite fitting. Sensei, who is the manifestation of 'the Spirit of Meiji', has lost his spirit with the end of Meiji period and thus decides to die.

\section{Conclusion}

Based on the analysis above, some conclusions can be made. There are five binary oppositions namely past against present, old against young, rural against urban, community against privacy, and family against individual. They are revealed to be parts of a bigger binary opposition namely traditional against modern. Furthermore, when they are compared with the situation in the real Meiji period, they reflect the state of mind of the Meiji Japanese, which is called the Spirit of Meiji. Therefore, in that regard, it can be concluded that the binary oppositions are the manifestation of the spirit of Meiji.

\section{References}

Abrams, Meyer Howard \& Geoffrey Galt Harpham. (2011). A Glossary of Literary Terms. Boston: Cengage Learning.

Barry, Peter. (2009). Beginning Theory: An Introduction to Literary and Cultural Theory. Manchester: Manchester University Press.

Barthes, Roland. (2002). S/Z (Richard Miller, Trans.). Oxford: Blackwell Publishing Ltd.

Frédéric, Louis. (2002). Japan Encyclopedia (Käthe Roth, Trans.). Cambridge: Belknap Press.

Fukuchi, Isamu. (1993). Kokoro and 'the Spirit of Meiji'. MonumentaNipponica, 48(4), 469-488. Retrieved from https://www.jstor.org/stable/2385293

Holman, Clarence Hugh. (1980). A Handbook to Literature. Indianapolis: ITT BobbsMerrill Educational Publishing Company, Inc.

Murphy, Murtagh John. (1972). Understanding Unseens: An Introduction to English Poetry and the English Novel for Overseas Students. London: George Allen and Unwin.

Myszka, Zachary. (2015). Ojosan and Emotion in Kokoro (Research Paper). Retrieved from http://www.academia.edu/ 16856335 /Ojosan_and_Emotion_in_Kokoro

Pyle, Kenneth B. (1969). New Generation in Meiji Japan: Problems of Cultural Identity, 1885-1895. Stanford: Stanford University Press.

Ricci, Jadon. (2016). The Devil in One's Heart: Traumatic Betrayal and its Consequences in NatsumeSōseki'sKokoro (Research Paper). Retrieved from http://www.academia.edu/33147820/T he_Devil_in_Ones_Heart_Traumatic_Betra yal_and_its_Consequences_in_Natsume_S \%C5\%8Dseki_s_Kokoro 
Smith, Greg. (1996). Binary opposition and sexual power in Paradise Lost. The Midwest Quarterly, 27(4), 383. Retrieved from http://go.galegroup.com/ps/i.do?p=AON $\mathrm{E} \& \mathrm{sw}=\mathrm{w} \& \mathrm{issn}=00263451 \& \mathrm{v}=2.1 \& \mathrm{it}=\mathrm{r} \& \mathrm{i}$ $\mathrm{d}=$ GALE$\% 7 C A 18521262 \&$ sid=googleSch olar\&linkaccess=fulltext

Sōseki, Natsume. (1966). 漱石全集

[SōsekiZenshū] (Vol. 13). Tokyo: Iwanami Shoten.

Sōseki, Natsume. (1969). Kokoro (Edwin McClellan, Trans.). Singapore: Tuttle Publishing.

Soukhanov, Anne H., David A. Jost, Kaethe Ellis et al. (Eds.). (1992). The American Heritage Dictionary of the English Language. Boston: Houghton Mifflin Harcourt.

Tyson, Lois. (2006). Critical Theory Today: A User-Friendly Guide. New York: Routledge. 